\title{
ASSESSING MERCURY MOBILITY IN SEDIMENT OF THE UNION CANAL, SCOTLAND, UK BY SEQUENTIAL EXTRACTION AND THERMAL DESORPTION
}

\author{
CAVOURA Olga ${ }^{\mathrm{a}, c^{\star}}$, DAVIDSON Christine $\mathrm{M}^{\mathrm{b}}{ }^{\mathrm{b}}$ KEENAN, Helen E ${ }^{\mathrm{a}}$, REIS, Ana $\mathrm{T}^{\mathrm{d}}$, \\ PEREIRA Eduarda ${ }^{d}$ \\ ${ }^{a}$ Department of Sanitary Engineering and Environmental Health, National School of Public \\ Health, Athens, Greece \\ ${ }^{b}$ WestCHEM, Department of Pure and Applied Chemistry, University of Strathclyde, \\ Glasgow, UK \\ ${ }^{\circ}$ Department of Civil and Environmental Engineering University of Strathclyde, Glasgow, UK \\ ${ }^{d}$ CESAM, Chemistry Department, University of Aveiro, Campus de Santiago, 3810-193 \\ Aveiro, Portugal
}

*corresponding author email: okavoura@esdy.edu.gr

Keywords mercury, sediment, mobility, extraction, thermal desorption

\section{Abstract}

The mobility of mercury $(\mathrm{Hg})$ was assessed in sediment from the Union Canal, Scotland, UK. Samples collected from the vicinity of a former munitions factory that manufactured mercury fulminate detonators were subjected to sequential extraction followed by cold vapor atomic absorption spectrometry (CVAAS) and direct analysis using thermal desorption (TD). The sequential extraction indicated that $>75 \%$ of mercury (up to $429 \mathrm{mg} \mathrm{kg}^{-1}$ ) was in mobile forms, with $<12 \%$ semi-mobile and $<23 \%$ non-mobile species. In the TD method, $>67 \%$ of the total $\mathrm{Hg}$ content was desorbed in the temperature range $100-250^{\circ} \mathrm{C}$ consistent with species weakly attached to the mineral matrix (tentatively identified as an iron (oxy)hydroxideassociated species). This predominance of mobile mercury species may arise from a lack of association between $\mathrm{Hg}$ and either organic matter or sulfur in the sediments. Further investigation of $\mathrm{Hg}$ mobilization, transport and assimilation/biomagnification is required both to determine whether there is a need for remediation of the sediment and to improve understanding of the biogeochemical cycling of $\mathrm{Hg}$ in shallow, oxic, freshwater systems.

\section{Introduction}

Mercury $(\mathrm{Hg})$ is a potentially toxic element distributed throughout the environment in different chemical species, where species refers to the 'specific form of an element defined as to isotopic composition, electronic or oxidation state, and/or complex or molecular structure' (IUPAC, 1997). With characteristics including global transfer and neurotoxicity, $\mathrm{Hg}$ is ranked third on the priority list of substances that pose a potential threat to human health (ASTDR 2013). The methylated form is especially of concern because it can be bioaccumulated and biomagnified up the food chain, ultimately resulting in the main source of human population $\mathrm{Hg}$ exposure through the consumption of contaminated fish. 
Between 90 and $95 \%$ of the total $\mathrm{Hg}$ in the environment is associated with sediment (Faust and Osman 1981) where interactions are governed almost exclusively by affinity for reduced sulfur (S) ligands (Dyrssen and Wedborg 1991). In sediment, HgS, an insoluble sulfide with very limited mobility is commonly encountered. Reduced $S$ ligands in organic matter (OM) also contribute significantly to strong sediment adsorption of $\mathrm{Hg}$ (Ravichandran, M. 2004). After saturation of the reduced $S$ ligands, $O$ and $N$ ligand associations are formed between $\mathrm{Hg}$ and OM (Skyllberg et al. 2006). In heavily polluted areas, weaker $\mathrm{Hg}$ adsorption to the inorganic matrix may occur if binding sites on OM become saturated (Hissier and Probst 2006).

Mobility, or ease of extractability, of $\mathrm{Hg}$ from sediment into the water column influences transport, thus the spread of contamination, and methylation since only dissolved $\mathrm{Hg}$ species can be taken up by the methylating bacteria involved. A range of techniques is available for determination of $\mathrm{Hg}$ mobility. Extraction procedures are used to remove $\mathrm{Hg}$ bound to sediment phases into operationally defined groups of more, or less, soluble species (Bloom et al. 2003; Rodrigues et al. 2010; Wallschlager et al. 1998). Based on the stepwise use of increasingly harsh reagents to remove $\mathrm{Hg}$ from increasingly stronger complexes, sequential extraction gives an indication of $\mathrm{Hg}$ mobility, availability and bioaccumulation potential; $\mathrm{Hg}$ removed under less harsh conditions could be released more readily in the environment whereas those forms requiring harsh reagents for their removal are considered less mobile and not bioavailable (Wallschlager et al. 1998). Reviews on sequential extraction procedures have been presented by Issaro et al. (2009) and Bacon and Davidson (2008).

Thermal desorption (TD) techniques are increasingly used to provide information on total $\mathrm{Hg}$ content, on $\mathrm{Hg}$ species in soil and sediment samples (Bollen et al. 2008; Reis et al. 2012; Saniewska and Beldowska 2017) and more recently on $\mathrm{Hg}$ speciation in aquatic and atmospheric particulate samples (Bełdowska et al. 2018). In TD speciation studies, $\mathrm{Hg}$ species adsorbed to solid particles are gradually removed by a stepwise increase in temperature, in a process analogous to sequential extraction where species are released by increasing harshness of extracting reagents. Individual $\mathrm{Hg}$ species are desorbed from the matrix within a characteristic temperature range. By comparing TD curves obtained from samples to TD curves of $\mathrm{Hg}$ standard materials, the $\mathrm{Hg}$ species present can be identified. The release of $\mathrm{Hg}$ species weakly associated with the sediment mineral matrix generally occurs at temperatures up to $250^{\circ} \mathrm{C}$, whilst higher desorption temperatures are required to release, for example, $\mathrm{Hg}$ species strongly associated with OM or present as HgS (Biester et al. 1999).

The Union Canal, Scotland, UK, has a history of $\mathrm{Hg}$ contamination arising from proximity to a munitions manufacturing site that produced detonators containing mercury fulminate for almost a century (Smith and Lassiere 2000). Following substantial redevelopment and regeneration in 2001-2002, which included dredging of sediment and soil excavation, the 
canal has become a major leisure facility used for boating and fishing. However, despite these remediation efforts, very high levels of $\mathrm{Hg}$ contamination persist in sediment close to the location of the former munitions factory (Cavoura et al. 2017). Methyl mercury levels in the canal sediments are currently low (Cavoura et al. 2017). However it is important that the mobility of $\mathrm{Hg}$ species present be determined to assess the likelihood of transport and potential for methylation.

The aim of this study was to determine the mobility of $\mathrm{Hg}$ species in sediment from the Union Canal, Scotland, UK using both sequential extraction followed by cold vapor atomic absorption spectrometry (CVAAS) and direct TDAAS techniques.

\section{Materials and methods}

\section{Sampling locations and method}

Eight sampling locations were selected from the Falkirk area of the canal, between Tamfourhill (1) and Polmont (10) at approximately $2 \mathrm{~km}$ intervals (Figure 1). Location 1 was part of a canal extension added in 2000-2001 as part of the canal regeneration. Sediment samples were collected and processed as described in Cavoura et al. (2017) i.e. they were dried at $30^{\circ} \mathrm{C}$ in a natural convection oven, sieved to $<2 \mathrm{~mm}$ and stored in glass bottles at room temperature.

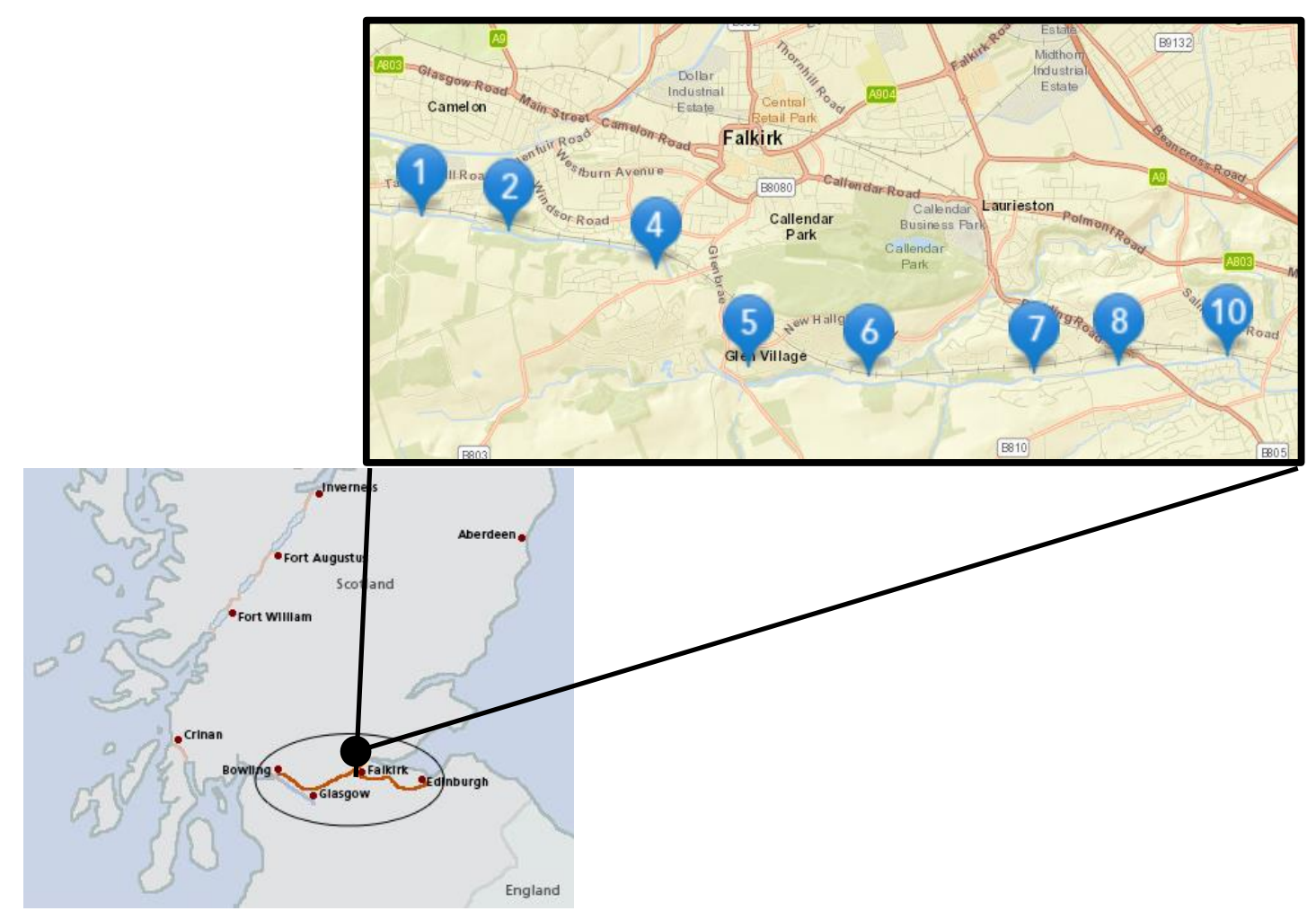

Fig. 1 Location of the Union Canal running from Falkirk to Edinburgh, Scotland, UK and sediment sampling locations 


\section{Reagents}

Reagents used were of analytical grade or higher purity. A stock standard $\mathrm{Hg}$ solution $(10 \mathrm{mg}$ $\mathrm{L}^{-1}$ in $10 \%(\mathrm{v} / \mathrm{v}) \mathrm{HNO}_{3}$ ) prepared from a $1000 \mathrm{mg} \mathrm{L}^{-1} \mathrm{Hg}$ standard solution $\left(\mathrm{Hg}\left(\mathrm{NO}_{3}\right)_{2}\right.$, Certipur, Merck, Leicester, UK) was stored at $4{ }^{\circ} \mathrm{C}$ and replaced monthly. Reagent-matched standard solutions with concentrations $<10 \mathrm{mg} \mathrm{L}^{-1}$ were prepared daily as required. Sodium borohydride $\left(\mathrm{NaBH}_{4}\right)$ reductant, a $3 \%$ solution in $1 \% \mathrm{NaOH}$, was prepared daily using $\mathrm{NaOH}$ pellets (AR, Mallinckrodt, Dublin, Ireland) and $\mathrm{NaBH}_{4}$ powder (GR for analysis, Merck KGaA, Darmstadt, Germany) and filtered (glass fibre filters, Pall A/E Glass fibre filters $1.0 \mu \mathrm{m}, 110$ $\mathrm{mm}$, Pall $\mathrm{GmbH}$, Dreieich, Germany) before use. Tin chloride $\left(\mathrm{SnCl}_{2}\right)$ reductant, $2 \%$ in $10 \%$ $\mathrm{HCl}$, was prepared from $\mathrm{SnCl}_{2} \cdot 2 \mathrm{H}_{2} \mathrm{O}$ (98\%, Alfa Aesar, Heysham, UK). A $4 \mathrm{M} \mathrm{HNO}_{3}$ solution for extraction of mobile $\mathrm{Hg}$ species was prepared by addition of $255 \mathrm{~mL} \mathrm{HNO}_{3}$ to approximately $250 \mathrm{~mL}$ deionized (DI) water and made up to $1000 \mathrm{~mL}$ with DI water. A $5.33 \mathrm{M} \mathrm{HNO}_{3}$ solution for extraction of semi-mobile $\mathrm{Hg}$ species was prepared by combining 1 part $\mathrm{HNO}_{3}$ with 2 parts DI water (1:2(v/v) $\left.\mathrm{HNO}_{3}: \mathrm{H}_{2} \mathrm{O}\right)$. Standard materials for $\mathrm{Hg}$ desorption curves were prepared as described in Reis et al. (2015).

\section{Analytical procedures}

Glassware was soaked in $10 \% \mathrm{v} / \mathrm{v} \mathrm{HNO}_{3}$ overnight and rinsed with $\mathrm{DI}$ water before use. Glass containers were used for storing $\mathrm{Hg}$ samples, standard solutions and reagents. Moisture content was determined on dried, sieved, test portions (BS 2000) and OM content was estimated by loss on ignition (Schumacher 2002).

Determination of total $\mathrm{Hg}$ concentration was performed using CVAAS (PE 2006) after microwave assisted digestion of samples with $\mathrm{HNO}_{3}$ (Berghoff Speedwave MWS-2 system). Analysis was performed following reduction with $3 \% \mathrm{NaBH}_{4}$ using a $\mathrm{MHS}-10 \mathrm{Hg} / \mathrm{Hydride}$ system (Perkin Elmer, Massachusetts, USA) operated in CV mode. Determinations were performed in triplicate after calibration of the instrument with reagent-matched standard solutions. Determination of total $\mathrm{Hg}$ concentration by TDAAS was carried out using a direct mercury analyser $\left(\mathrm{LECO}^{\circledR}\right.$, model AMA-254) with gold amalgamation and AAS detection system using a silicon diode detector at $253.6 \mathrm{~nm}$. Further details can be found in Reis et al. (2013). Determinations were performed in triplicate.

Operationally-defined species mobility was determined using extractants of increasing acid strengths as recommended in USEPA Method 3200 (USEPA 2014). Extraction of mobile $\mathrm{Hg}$ species was achieved by microwave irradiation (Berghoff Speedwave MWS-2 microwave system, Berghof Products + Instruments $\mathrm{GmbH}$, Eningen, Germany) with $4 \mathrm{M} \mathrm{HNO}_{3}$ at $100{ }^{\circ} \mathrm{C}$ (Rahman and Kingston 2005). Extraction of semi-mobile species was achieved using 5.33 M $\mathrm{HNO}_{3}$ extractant and a combination of vortex, heating (PD Group, Medingen, Dresden, 
Germany) and centrifugation (Han 2003). Both extracts were analysed by CVAAS following reduction with $3 \% \mathrm{NaBH}_{4}$ as described for the determination of total $\mathrm{Hg}$ concentration. Nonmobile species such as $\mathrm{HgS}$ and $\mathrm{HgSe}$ were determined from the difference between total $\mathrm{Hg}$ concentration and the sum of the concentrations of mobile and semi-mobile species.

Species identification using TDAAS was carried out using a direct mercury analyser with gold amalgamation (LECO ${ }^{\circledR}$, model AMA-254). Desorption curves were obtained for standard materials $\mathrm{HgCl}_{2}, \mathrm{Hg}$ associated with iron(III)oxide ( $\left.\mathrm{HgFe}\right), \mathrm{Hg}$-humic acid complex $(\mathrm{HgHA})$, and $\mathrm{HgS}$ (Figure 2). As expected (Reis et al. 2015) lower desorption temperatures were observed for $\mathrm{HgCl}_{2}$ and $\mathrm{HgFe}$ than for $\mathrm{HgHA}$ and $\mathrm{HgS}$. The curves for $\mathrm{HgFe}$ and $\mathrm{HgCl}_{2}$ showed peaks between 75 and $285{ }^{\circ} \mathrm{C}$ (maximum $\sim 170{ }^{\circ} \mathrm{C}$ ) and between 95 and $285{ }^{\circ} \mathrm{C}$ (maximum $\sim 170{ }^{\circ} \mathrm{C}$ ) respectively. The curve obtained for $\mathrm{HgHA}$ spanned the temperature range $125-655^{\circ} \mathrm{C}$ (maximum $\sim 240{ }^{\circ} \mathrm{C}$ ) with three peaks corresponding to the release of $\mathrm{Hg}$ bound to S, O and $\mathrm{N}$ groups in OM (Reis et al. 2015). Desorption of HgS occurred over the temperature interval $240-370{ }^{\circ} \mathrm{C}$, (maximum $\sim 306{ }^{\circ} \mathrm{C}$ ). The curves for $\mathrm{HgCl}_{2}$ and $\mathrm{HgFe}$ overlapped preventing identification of these species individually from TD curves alone. While $\mathrm{HgS}$ was well separated from $\mathrm{HgCl}_{2}$ and $\mathrm{HgFe}$, there was overlap with desorption from $\mathrm{Hg}$ from $\mathrm{S}$ bonding sites in the $\mathrm{HgHA}$ standard. These limitations are considered further in Reis et al. (2015).

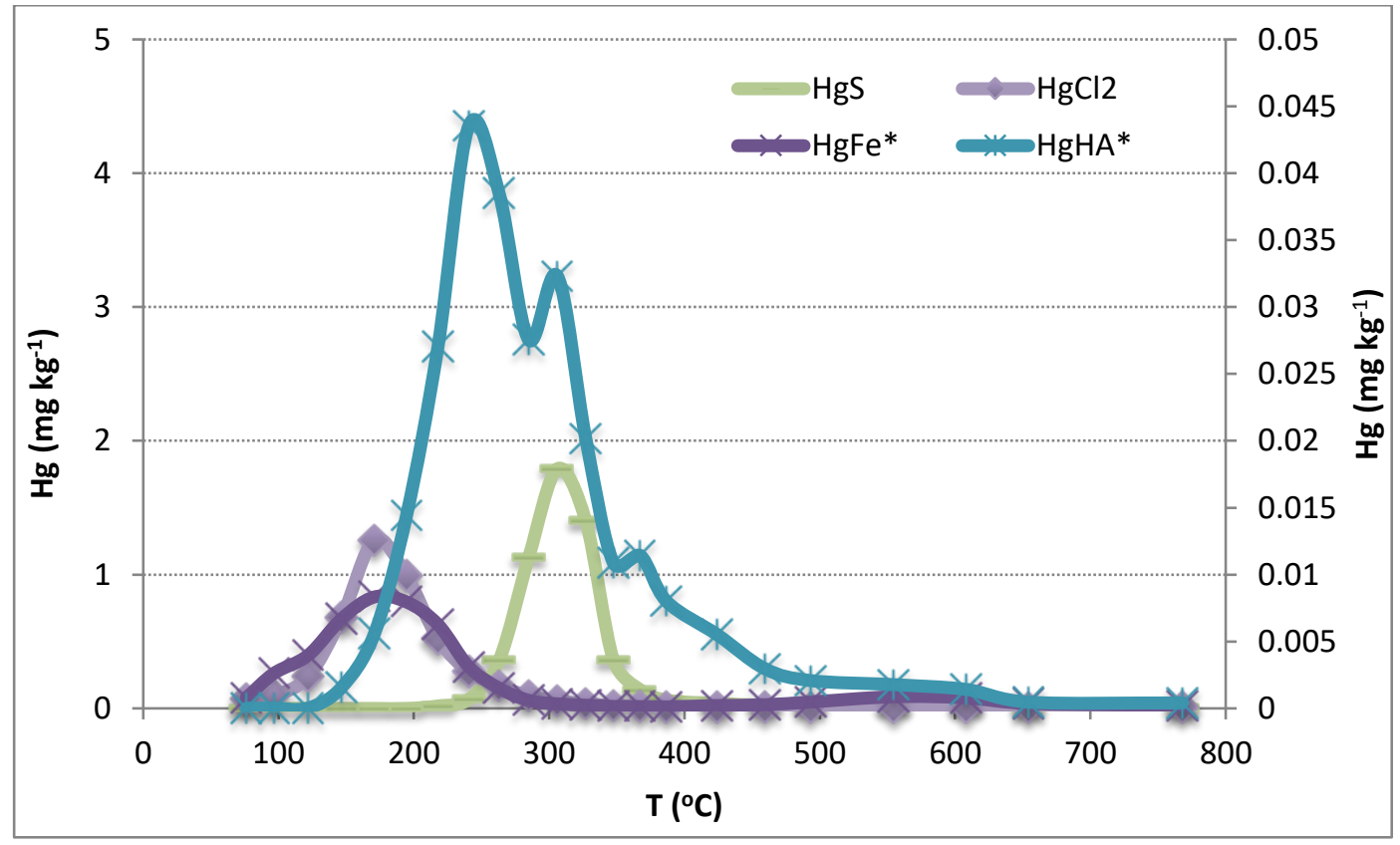

Fig. 2 Thermal desorption curves for standard $\mathrm{Hg}$ materials

\section{Limits of detection and quality control}


Limit of detection (LOD) for CVAAS was $0.067 \mathrm{mg} \mathrm{kg}^{-1}$. Recovery of $\mathrm{Hg}$ from CRM BCR 320 R Channel Sediment containing $0.85 \pm 0.09 \mathrm{mg} \mathrm{kg}^{-1} \mathrm{Hg}$ (Geel, Belgium) was $116 \pm 20.3 \%$ $(\mathrm{n}=3)$. For TDAAS, the LOD was $0.020 \mathrm{mg} \mathrm{kg}^{-1}$. Recovery of $\mathrm{Hg}$ from CRM MESS-3 Marine Sediment containing $0.091 \pm 0.009 \mathrm{mg} \mathrm{kg}^{-1} \mathrm{Hg}$ was $107 \pm 2.05 \%(\mathrm{n}=6)$.

\section{Results and discussion}

Sampling locations, OM content and total $\mathrm{Hg}$ concentrations determined by both CVAAS and TDAAS are given in Table 1.

Table 1 Location, characteristics and total mercury concentrations of sediment samples from the Union Canal, Scotland, UK

\begin{tabular}{ccccc}
\hline Location & Latitude Longitude & $\begin{array}{c}\mathrm{OM} \\
(\%)\end{array}$ & $\begin{array}{c}\mathrm{Hg} \text { (CVAAS) } \\
\mathrm{mg} \mathrm{kg}^{-1}\end{array}$ & $\begin{array}{c}\mathrm{Hg} \text { (TDAAS) } \\
\mathrm{mg} \mathrm{kg}^{-1}\end{array}$ \\
\hline $\mathbf{1}$ & $55.996^{\circ} \mathrm{N}, 3.830^{\circ} \mathrm{W}$ & 6.84 & $21.9 \pm 0.6$ & $25.1 \pm 0.1$ \\
$\mathbf{2}$ & $55.994^{\circ} \mathrm{N}, 3.818^{\circ} \mathrm{W}$ & 14.6 & $80.2 \pm 6.1$ & $100 \pm 5$ \\
$\mathbf{4}$ & $55.992^{\circ} \mathrm{N}, 3.795^{\circ} \mathrm{W}$ & 18.1 & $410 \pm 47$ & $451 \pm 7$ \\
$\mathbf{5}$ & $55.984^{\circ} \mathrm{N}, 3.787^{\circ} \mathrm{W}$ & 15.6 & $565 \pm 48$ & $542 \pm 27$ \\
$\mathbf{6}$ & $55.984^{\circ} \mathrm{N}, 3.774^{\circ} \mathrm{W}$ & 10.9 & $423 \pm 110$ & $433 \pm 6$ \\
$\mathbf{7}$ & $55.983^{\circ} \mathrm{N}, 3.746^{\circ} \mathrm{W}$ & 6.12 & $199 \pm 23$ & $189 \pm 2$ \\
$\mathbf{8}$ & $55.984^{\circ} \mathrm{N}, 3.735^{\circ} \mathrm{W}$ & 13.7 & $300 \pm 30$ & $274 \pm 18$ \\
$\mathbf{1 0}$ & $55.983^{\circ} \mathrm{N}, 3.715^{\circ} \mathrm{W}$ & 8.47 & $21.9 \pm 0.6$ & $31.3 \pm 1.9$
\end{tabular}

Sediment OM content ranged from $6.12 \pm 1.4$ to $18.1 \pm 1.1 \%$. Total $\mathrm{Hg}$ concentrations as determined by CVAAS ranged from a minimum of $22.0 \pm 0.6 \mathrm{mg} \mathrm{kg}^{-1}$ at location 1 , to a maximum of $565 \pm 48 \mathrm{mg} \mathrm{kg}^{-1}$ at location 5 . No statistical difference was found between the results obtained by the CVAAS and TDAAS methods (non-parametric data, Wilcoxon matched pairs T-test, Tcalc $>$ Tcrit, $n=8, p<0.05$ ). Despite the affinity of $\mathrm{Hg}$ for $\mathrm{OM}$ generally reported, the two parameters were not significantly correlated $\left(r^{2}=0.376, p>0.05\right)$. A previous study (Cavoura et al. 2017) also found no significant association between $\mathrm{Hg}$ and OM content $\left(r^{2}=\right.$ $0.534, p>0.05$ ) in Union Canal sediment samples.

The sequential extraction results (Figure 3 ) indicated that over $75 \%$ of $\mathrm{Hg}$ species present were weakly bonded to the sediment. Specifically, between $75.9 \%$ of the total $\mathrm{Hg}$ content at location 5 (corresponding to $429 \mathrm{mg} \mathrm{kg}^{-1} \mathrm{of} \mathrm{Hg}$ ) and $94.0 \%$ of the total content at location 7 (187 $\mathrm{mg} \mathrm{kg}^{-1}$ of $\mathrm{Hg}$ ) was extracted in the first step (4 $\mathrm{M} \mathrm{HNO}_{3}$ ). This fraction includes $\mathrm{Hg}$ species such as water soluble $\mathrm{HgCl}_{2}$, weak acid soluble species and weakly bound organic 
$\mathrm{Hg}$ species such as MeHg (Rahman and Kingston 2005). The majority of the remaining $\mathrm{Hg}$ was in non-mobile forms, with very little semi-mobile $\mathrm{Hg}$ present.

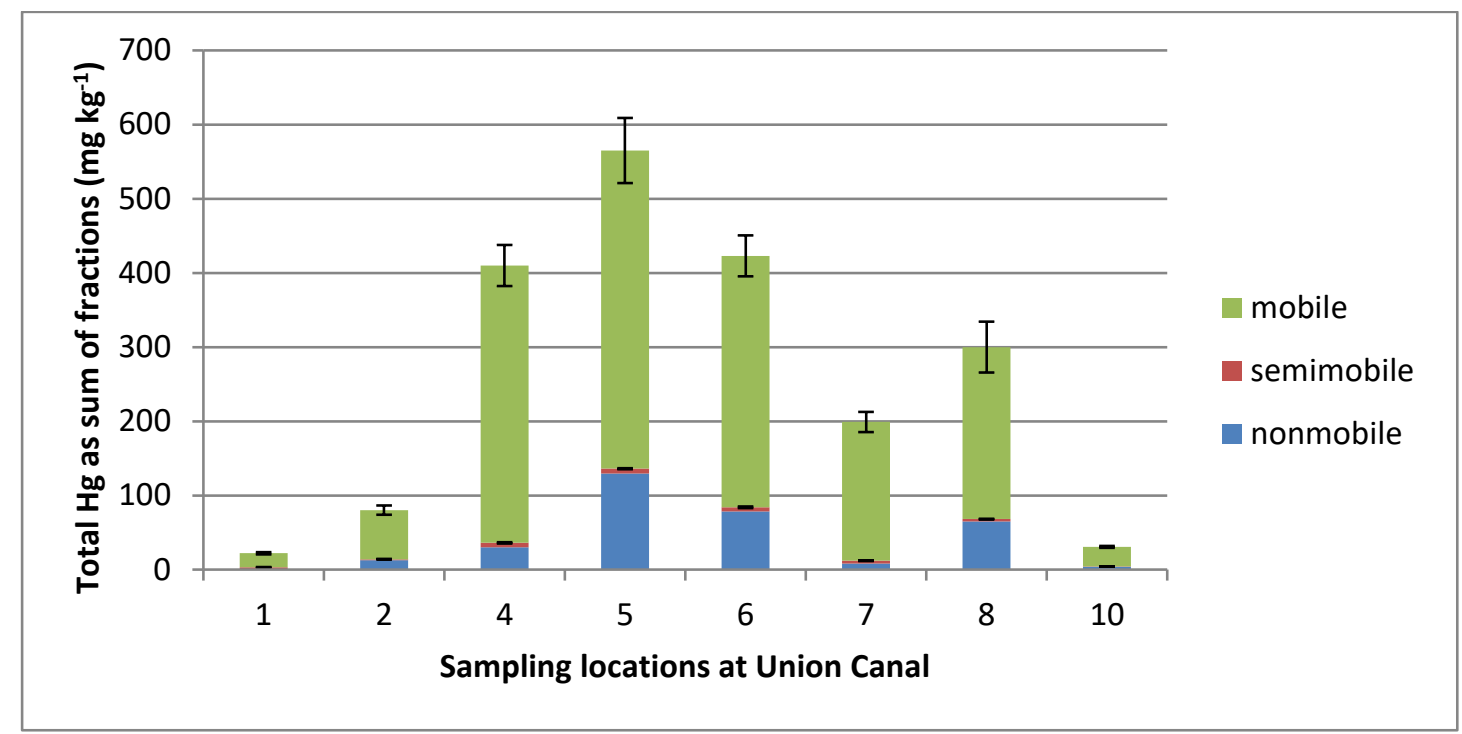

Fig. 3 Total $\mathrm{Hg}$ concentration expressed as a sum of $\mathrm{Hg}$ in fractions in sediments of the Union Canal, Scotland, U.K. (mean $\pm S D, n=3$ )

The TD results similarly indicated that the majority of $\mathrm{Hg}$ present was weakly bonded to the sediment. Desorption of $>67 \%$ of $\mathrm{Hg}$ species in all samples occurred in the temperature range 100-250 ${ }^{\circ} \mathrm{C}$ coincident with $\mathrm{HgFe}$ and/or $\mathrm{HgCl}_{2}$ TD curves. Samples 2, 5, 6 and 7 showed one major peak at approximately $160{ }^{\circ} \mathrm{C}$ consistent with $\mathrm{HgFe}$ and/or $\mathrm{HgCl}_{2}$ but - in particular for samples 5 and 6 - with noticeable tailing into the temperature domain associated with $\mathrm{HgHA}$ (Figure 4). This is broadly consistent with the findings of the sequential extraction where samples 5 and 6 contained the highest proportions of $\mathrm{Hg}$ in forms released in later steps of the protocol. At sites 1 and 10 (the least contaminated sites) the speciation was similar though here there was a distinct second peak at a temperature consistent with one of the peaks observed for the $\mathrm{HgHA}$ standard (site 1) or with either $\mathrm{HgHA}$ or HgS (site 10) (Figure 4). In the TD curves for sediments from sites 4 and 8 , the $\mathrm{Hg}$ release peaked at a higher temperature of around $200^{\circ} \mathrm{C}$ (Figure 4). 

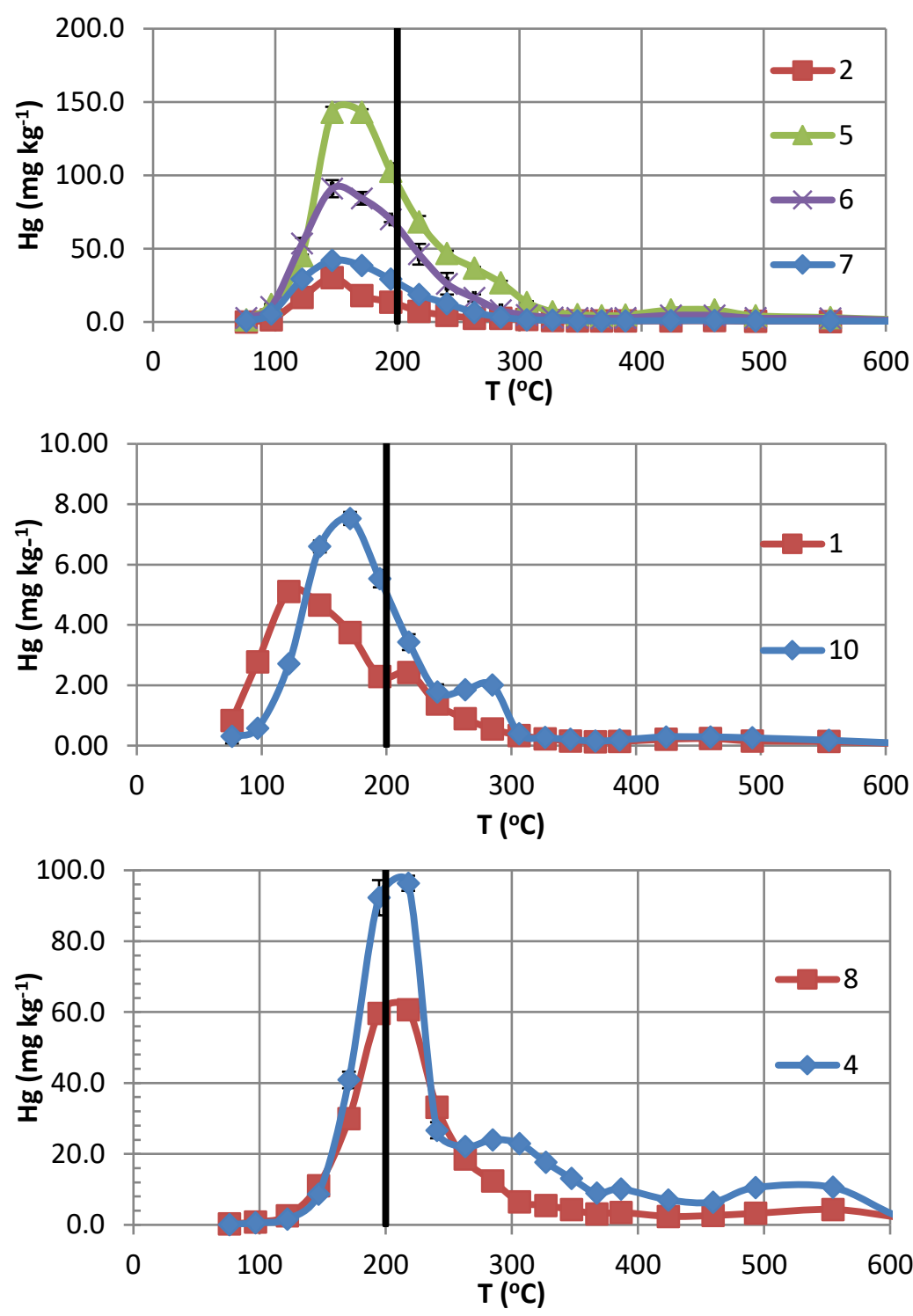

Fig. 4 Averaged thermal desorption curves for $\mathrm{Hg}$ in sediments from the Union Canal at locations 2,5,6,7 (upper), 1 and 10 (middle), 4 and 8 (lower)

This dominance of mobile, weakly associated $\mathrm{Hg}$ species in sediment is not common. Mobile species typically account for only a small proportion of the $\mathrm{Hg}$ content, with less mobile species strongly associated with $S$ often the major forms (Oliveri et al. 2016; Beldowski and Pempkowiak 2003; Ram et al. 2009; Covelli et al. 2012; Frohne and Rinklebe 2013; PinedoHernández et al. 2015; Garcia-Ordiales et al. 2018). The speciation of $S$ is of course an important factor in such relationships (Liu et al. 2018). Only the reduced form is a strong $\mathrm{Hg}$ binder. Previous work in this study area (Cavoura et al. 2017) found no significant relationship between $\mathrm{Hg}$ and $\mathrm{S}$ content $\left(\mathrm{r}^{2}=0.140, \mathrm{p}>0.05\right)$. The fact that the sediment is present as a thin layer $(<10 \mathrm{~cm}$ thick), typically overlain by $<2 \mathrm{~m}$ of water, and frequently re-suspended by 
passing boats, may mean that it is well-oxygenated with limited potential for the formation of reduced $\mathrm{S}$ species.

The nature of the dominant $\mathrm{Hg}$ species found in the current study cannot be determined with certainty. However, conclusions can be drawn about its likely identity. Sequential extraction indicates that the species is mobile, and the relatively low temperate at which it appears in the TD analysis is consistent with desorption mainly from the mineral matrix rather than association with OM (Biester et al. 1999). Such species could be $\mathrm{HgCl}_{2}, \mathrm{Hg}$ associated with $\mathrm{Fe}$, or another mineral-matrix bound $\mathrm{Hg}$ species released early in the extraction procedure and desorbed at a similar temperature to $\mathrm{HgCl}_{2}$ and $\mathrm{HgFe}$. Due to its high solubility and stability in solution (Kim et al. $2004 \mathrm{~b}$ ), $\mathrm{HgCl}_{2}$ is not usually bound to sediment except in areas with high $\mathrm{HgCl}_{2}$ contamination for example from its use as a preservative in wood treatment (Bollen et al. 2008). While $\mathrm{HgO}$ would be released at the correct stage of the extraction, TD would occur at a higher temperature (Biester et al. 1999). Additionally, $\mathrm{HgO}$ is not widespread in the environment and is generally associated with mine tailings (Biester et al. 1999).

It is therefore suggested that the major form of $\mathrm{Hg}$ in Union Canal sediment is an $\mathrm{Fe}$ (hydr)oxide associated species. Extraction of such a species would occur in the first step of the sequential extraction scheme used (Rahman and Kingston 2005) and the dominant peak in the TD for the majority of samples occurred at a temperature consistent with the TD curve of the $\mathrm{HgFe}$ standard. Significant positive correlation between $\mathrm{Hg}$ concentration and $\mathrm{Fe}$ content has been previously reported in Union Canal sediments $\left(r^{2}=0.670, p<0.05\right)$ (Cavoura et al. 2017). Previous studies involving extended X-ray absorption fine structure (Kim et al. 2004a, 2004b) have confirmed that, in the absence of bonding with OM or reduced S species, adsorption of $\mathrm{Hg}$ to $\mathrm{Fe}$ (hydr)oxide surfaces can occur.

While mobile $\mathrm{Hg}$ species have been shown to be present, to what extent mobilization from the canal sediment in fact occurs depends on many factors. Zhu et al. (2018) recommended that changes in redox potential, $\mathrm{Hg}$ chemical speciation and the source and nature of $\mathrm{OM}$ all must be considered when assessing mobilization. Even following release from sediment, whether $\mathrm{Hg}$ will remain solvated, become associated with suspended particulate matter, or precipitate depends on numerous factors such as $\mathrm{pH}$, composition and redox conditions of the water. However, some mobilization of $\mathrm{Hg}$ from contaminated sediment in the Union Canal (whether in solution or suspension) is strongly indicated by increased $\mathrm{Hg}$ levels in a connected waterway (Cavoura et al. 2017). Similarly, while mobility is used as an indicator of bioavailability, assimilation of $\mathrm{Hg}$ inside organisms depends not only on $\mathrm{Hg}$ speciation but also on physicochemical and physiological conditions. To assess whether biological uptake is occurring would require direct cellular analysis of relevant biota. In the 
same way, any potential for biomagnification of $\mathrm{Hg}$ in the canal would require analysis of, for example, predatory fish.

\section{Conclusions}

Sequential extraction followed by analysis of extracts by CVAAS and direct analysis by TDAAS both indicated that $\mathrm{Hg}$ in the sediment of the Union Canal in the vicinity of a former munitions factory was primarily in mobile forms, weakly associated with the mineral matrix. This unusually high mobility may be a consequence of limited association between $\mathrm{Hg}$ and $\mathrm{OM}$ or S. Results suggest that the dominant species present is $\mathrm{Hg}$ associated with iron (oxy)hydroxide. Shallow water depth and the fact that only a thin layer of sediment is present, which undergoes frequent re-suspension, may limit formation of the reduced $S$ species usually responsible for binding the majority of $\mathrm{Hg}$ in sediment.

Further research to determine the redox status; $\mathrm{Hg}$, Fe and S speciation; and the nature of $\mathrm{OM}$ present would be beneficial to improve understanding of the processes governing the binding of $\mathrm{Hg}$ in the canal sediment. Analysis of water and suspended sediment could help elucidate whether mobilization is taking place. Analysis of biota would be of interest to determine whether assimilation (potentially leading to the formation of methylmercury) and biomagnification are occurring and, if so, to what extent. Further studies are required to assess whether mobile $\mathrm{Hg}$ species are predominant in other shallow freshwater systems where limited sediment depth may preclude the formation of reduced binding sites.

\section{Acknowledgements}

The authors wish to thank Scottish Canals (formerly British Waterways) for providing background information on the canal system and granting permission to sample.

\section{Funding}

This research did not receive any specific grant from funding agencies in the public, commercial or not-for-profit sectors.

\section{References}

ATSDR (2013) Minimal Risk Levels (MRLs) Toxic Substances Portal. Available at http://www.atsdr.cdc.gov/mrls/pdfs/atsdr_mrls_july_2013.pdf.

Bacon JR, Davidson CM (2008) Is there a future for sequential chemical extraction? Analyst $13325-46$

Biester H, Gosar M, Muller G (1999) Mercury speciation in tailings of the Idrija mercury mine. J. Geochem. Explor. 65 195-204 
Bełdowska M, Saniewska D, Gębka K, Kwasigroch U, Korejwo E, Kobos J (2018) Simple screening technique for determination of adsorbed and absorbed mercury in particulate matter in atmospheric and aquatic environment. Talanta 182 340-347

Beldowski J, Pempkowiak J. (2003) Horizontal and vertical variabilities of mercury concentration and speciation in sediment of the Gdansk Basin, Southern Baltic Sea. Chemosphere 53 645-654

Bloom NS, Preus E, Katon J, Hitner M. (2003) Selective extractions to assess the biogeochemically relevant fractionation of inorganic mercury in sediments and soils. Anal. Chim. Acta 479 233-248

Bollen A, Wenke A, Biester $\mathrm{H}$ (2008) Mercury speciation analyses in $\mathrm{HgCl}$-contaminated soils and groundwater - Implications for risk assessment and remediation strategies. Water Res. 42 91-100

BS (2000) British Standards ISO 12880:2000: Characterisation of sludges - Determination of dry residue and water content. British Standards Institution, London, UK

Cavoura O, Brombach CC, Cortis R, Davidson CM, Gajdosechova Z, Keenan HE, Krupp EM (2017) Mercury alkylation in freshwater sediments from Scottish Canals. Chemosphere 183 27-35

Dyrssen D, Wedborg M (1991) The Sulfur-Mercury(II) System in Natural-Waters. Water Air Soil Pollut. 56 507-519

Faust SD, Osman MA (1981) Chemistry of natural waters. Ann Arbor, Mich: Ann Arbor Science Publishers, Inc. Mercury, arsenic, lead, cadmium, selenium, and chromium in aquatic environments, pp. 200-225.

Garcia-Ordiales E, Covelli S, Rico JM, Roquení N, Fontolan G, Flor-Blanco G, Cienfuegos P, Loredo J (2018) Occurrence and speciation of arsenic and mercury in estuarine sediments affected by mining activities (Asturias, northern Spain). Chemosphere 198 281-289

Han Y, Kingston HM, Boylan HM, Rahman GMM, Shah S, Richter RC, Link DD, Bhandari S (2003) Speciation of mercury in soil and sediment by selective solvent and acid extraction. Anal. Bioanal. Chem. 375 428-436

Haynes N (2015) Scotland's Canals, Historic Scotland in association with Scottish Canals. ISBN 9781849171656

Hissier C, Probst JL. (2006) Chlor-alkali industrial contamination and riverine transport of mercury: Distribution and partitioning of mercury between water, suspended matter, and bottom sediment of the Thur River, France. Appl. Geochem. 90 1837-1854

Issaro N, Abi-Ghanem C, Bermond A (2009) Fractionation studies of mercury in soils and sediments: A review of the chemical reagents used for mercury extraction. Anal. Chim. Acta $6311-12$

Kim CS, Rytuba JJ, Brown GE (2004a) EXAFS study of mercury(II) sorption to Fe- and Al(hydr)oxides I. Effects of pH. J. Colloid Interface Sci. 271 1-15

Kim CS, Rytuba JJ, Brown GE (2004b) EXAFS study of mercury(II) sorption to Fe- and Al(hydr)oxides - II. Effects of chloride and sulfate. J. Colloid Interface Sci. 270 9-20 
Liu J, Jiang T, Wang F, Zhang J, Wang D, Huang R, Yin D, Liu Z, Wang J (2018) Inorganic sulfur and mercury speciation in the water level fluctuation zone of the Three Gorges Reservoir, China: The role of inorganic reduced sulfur on mercury methylation. Environ. Pollut. 237 1112-1123

Oliveri E, Manta DS, Bonsignore M, Cappello S, Tranchida G, Bagnato E, Sabatino N, Santisi S, Sprovieri M, (2016) Mobility of mercury in contaminated marine sediments: Biogeochemical pathways. Mar. Chem. 186 1-10

Pinedo-Hernández J, Marrugo-Negrete J, Díez S (2015) Speciation and bioavailability of mercury in sediments impacted by goldmining in Colombia. Chemosphere119 1289-1295

Rahman GMM, Kingston HM (2005) Development of a microwave-assisted extraction method and isotopic validation of mercury species in soils and sediments. J. Anal. At. Spectrom. 20 183-191

Ravichandran M (2004) Interactions between mercury and dissolved organic matter- a review. Chemosphere 55 319-331

Reis AT, Coelho JP, Rodrigues SM, Rocha R, Davidson CM, Duarte AC, Pereira E (2012) Development and validation of a simple thermo-desorption technique for mercury speciation in soils and sediments Talanta 99 363-368

Reis AT, Coelho JP, Rucandio I, Davidson CM, Duarte AC, Pereira E (2015) Thermodesorption: A valid tool for mercury speciation in soils and sediments? Geoderma 237-238 98-104

Rodrigues SM, Henriques B, Coimbra J, Ferreira da Silva E, Pereira ME, Duarte AC (2010) Water-soluble fraction of mercury, arsenic and other potentially toxic elements in highly contaminated sediments and soils. Chemosphere 78 1301-1312

Saniewska D, Bełdowska M (2017) Mercury fractionation in soil and sediment samples using thermo-desorption method. Talanta 168 152-161

Schumacher B (2002) Methods for the determination of total organic carbon (TOC) in soil and sediment US EPA Ecological risk assessment support centre Office of Research and Development US EPA

Skyllberg U, Bloom PR, Qian J, Lin CM, Bleam WF (2006) Complexation of mercury(II) in soil organic matter: EXAFS evidence for linear two-coordination with reduced sulfur groups. Environ. Sci. Technol. 40 4174-4180

Smith NA, Lassière OL (2000) Resolving Mercury Contamination in the Union Canal, Scotland in The Millennium Link - The rehabilitation of the Forth and Clyde and Union canals. G. Fleming Thomas Telford Publishing

USEPA (2014) EPA METHOD 3200 Mercury species fractionation and quantification by microwave assisted extraction, selective solvent extraction and/or solid phase extraction

Wallschlager D, Desai MVM, Spengler M, (1998) Mercury speciation in floodplain soil and sediment along a contaminated river transect. J. Environ. Qual. 27 1034-1044

Zhu W, Song Y, Adediran GA, Jiang T, Reis AT, Pereira E, Skyllberg U, Bjorn E (2018) Mercury transformations in resuspended contaminated sediment controlled by redox 
conditions, chemical speciation and sources of organic matter. Geochim. Cosmochim. Acta $220158-179$ 